\title{
Front Matter: Volume 6806
}

, "Front Matter: Volume 6806," Proc. SPIE 6806, Human Vision and Electronic Imaging XIII, 680601 (11 March 2008); doi: 10.1117/12.792498

SPIE. Event: Electronic Imaging, 2008, San Jose, California, United States 


\section{PROCEEDINGS Electronic Imaging \\ Sclence and Tochnology}

\section{Human Vision and Electronic Imaging XIII}

Bernice E. Rogowitz

Thrasyvoulos N. Pappas

Editors

28-31 January 2008

San Jose, California, USA

Sponsored and Published by

IS\&T-The Society for Imaging Science and Technology

SPIE 
The papers included in this volume were part of the technical conference cited on the cover and title page. Papers were selected and subject to review by the editors and conference program committee. Some conference presentations may not be available for publication. The papers published in these proceedings reflect the work and thoughts of the authors and are published herein as submitted. The publishers are not responsible for the validity of the information or for any outcomes resulting from reliance thereon.

Please use the following format to cite material from this book:

Author(s), "Title of Paper," in Human Vision and Electronic Imaging XIII, edited by Bernice E. Rogowitz, Thrasyvoulos N. Pappas, Proceedings of SPIE-IS\&T Electronic Imaging, SPIE Vol. 6806, Article CID Number (2008).

ISSN 0277-786X

ISBN 9780819469786

Copublished by

SPIE

P.O. Box 10, Bellingham, Washington 98227-0010 USA

Telephone +1 3606763290 (Pacific Time) · Fax +1 3606471445

SPIE.org

and

IS\&T-The Society for Imaging Science and Technology

7003 Kilworth Lane, Springfield, Virginia, 22151 USA

Telephone +1 7036429090 (Eastern Time) · Fax +1 7036429094

imaging.org

Copyright @ 2008, Society of Photo-Optical Instrumentation Engineers and The Society for Imaging Science and Technology.

Copying of material in this book for internal or personal use, or for the internal or personal use of specific clients, beyond the fair use provisions granted by the U.S. Copyright Law is authorized by the publishers subject to payment of copying fees. The Transactional Reporting Service base fee for this volume is $\$ 18.00$ per article (or portion thereof), which should be paid directly to the Copyright Clearance Center (CCC), 222 Rosewood Drive, Danvers, MA 01923. Payment may also be made electronically through CCC Online at copyright.com. Other copying for republication, resale, advertising or promotion, or any form of systematic or multiple reproduction of any material in this book is prohibited except with permission in writing from the publisher. The CCC fee code is 0277-786X/08/ $\$ 18.00$.

Printed in the United States of America.

Paper Numbering: Proceedings of SPIE follow an e-First publication model, with papers published first online and then in print and on CD-ROM. Papers are published as they are submitted and meet publication criteria. A unique, consistent, permanent citation identifier (CID) number is assigned to each article at the time of the first publication. Utilization of CIDs allows articles to be fully citable as soon they are published online, and connects the same identifier to all online, print, and electronic versions of the publication. SPIE uses a six-digit CID article numbering system in which:

- The first four digits correspond to the SPIE volume number.

- The last two digits indicate publication order within the volume using a Base 36 numbering system employing both numerals and letters. These two-number sets start with 00, 01, 02, 03, 04, 05, 06, 07, 08 , 09, OA, OB ... 0Z, followed by 10-1Z, 20-2Z, etc.

The CID number appears on each page of the manuscript. The complete citation is used on the first page, and an abbreviated version on subsequent pages. Numbers in the index correspond to the last two digits of the six-digit CID number. 


\section{Contents}

$\begin{array}{ll}\text { ix } & \text { Conference Committee } \\ \text { xi Introduction }\end{array}$

SESSION 1 KEYNOTE SESSION: CELEBRATING 20 YEARS OF HVEI I

680602 Image statistics and surface perception (Keynote Paper) [6806-01]

E. H. Adelson, Massachusetts Institute of Technology (USA)

680603 The perception of simulated materials (Keynote Paper) [6806-02]

H. Rushmeier, Yale Univ. (USA)

SESSION 2 KEYNOTE SESSION: CELEBRATING 20 YEARS OF HVEI II

680604 Single-photon imaging inspired by human vision (Keynote Paper) [6806-03]

H. Mohseni, Northwestern Univ. (USA)

680605 Appearance of images (Keynote Paper) [6806-04]

K. K. De Valois, Univ. of California, Berkeley (USA); T. Takeuchi, NTT Corp. (Japan);

T. D. Wickens, Univ. of California, Berkeley (USA)

\section{SESSION 3 CORTICAL MODELING AND REPRESENTATION}

680607 Statistics of natural scenes and the cortical representation of color [6806-06]

G. A. Cecchi, A. R. Rao, T.J. Watson IBM Research Ctr. (USA); Y. Xiao, E. Kaplan, Mount Sinai School of Medicine (USA)

680608 Combining MRI and VEP imaging to isolate the temporal response of visual cortical areas [6806-07]

T. Carney, Neurometrics Institute (USA) and Univ. of California at Berkeley (USA); J. Ales,

Smith Kettlewell Eye Research Institute (USA); S. A. Klein, Univ. of California at Berkeley (USA)

680609 Mathematical modeling and the neuroscience of metaphor [6806-08]

H. K. Rising III, Consultant (USA)

\section{SESSION 4 PERCEPTION AND HIGH DYNAMIC RANGE DISPLAYS}

6806 OA Separating the effects of glare from simultaneous contrast [6806-09]

A. Rizzi, M. Pezzetti, Univ. degli Studi di Milano (Italy); J. J. McCann, McCann Imaging (USA)

$6806 \mathrm{OB}$ Extending quality metrics to full luminance range images [6806-10]

T. O. Aydın, R. Mantiuk, H.-P. Seidel, MPI Informatik (Germany) 
6806 0C Perception-based contrast enhancement model for complex images in high dynamic range [6806-11]

A. Yoshida, G. Krawczyk, K. Myszkowski, H.-P. Seidel, Max-Planck-Institut für Informatik (Germany)

\section{SESSION 5 VISION AND GRAPHICS}

6806 OD Perceived quality assessment of polygonal meshes using observer studies: a new extended protocol [6806-12]

S. Silva, B. Sousa Santos, J. Madeira, Univ. de Aveiro (Portugal); C. Ferreira, Univ. de Aveiro (Portugal) and Univ. de Lisboa (Portugal)

6806 OE Dimensionality of visual complexity in computer graphics scenes [6806-13]

G. Ramanarayanan, K. Bala, Cornell Univ. (USA); J. A. Ferwerda, Rochester Institute of Technology (USA); B. Walter, Cornell Univ. (USA)

\section{SESSION 6 NEXT-GENERATION INTERACTIVE ENVIRONMENTS}

6806 OF Beyond image quality: designing engaging interactions with digital products [6806-14] H. de Ridder, Delft Univ. of Technology (Netherlands); M. C. Rozendaal, Eindhoven Univ. of Technology (Netherlands)

6806 OG Impact of sound on image-evoked emotions [6806-15]

R. Van Egmond, Delft Univ. of Technology (Germany)

$6806 \mathrm{OH}$ The impact of interactive manipulation on the recognition of objects [6806-16] F. Meijer, E. L. van den Broek, Univ. of Twente (Netherlands); T. Schouten, Radboud Univ. Nijmegen (Netherlands)

6806 Ol Virtual hand: a 3D tactile interface to virtual environments [6806-17]

B. E. Rogowitz, P. Borrel, IBM Thomas J. Watson Research Ctr. (USA)

$68060 \mathrm{~J}$ Touch, tools, and telepresence: embodiment in mediated environments [6806-57] W. A. IJsselsteijn, A. Haans, Eindhoven Univ. of Technology (Netherlands)

6806 OK Augmented reality in surgical procedures [6806-18] E. Samset, Univ. of Oslo (Norway); D. Schmalstieg, Graz Univ. of Technology (Austria); J. Vander Sloten, Katholieke Univ. Leuven (Belgium); A. Freudenthal, Delft Univ. of Technology (Netherlands); J. Declerck, Siemens Molecular Imaging (United Kingdom);

S. Casciaro, Institute of Clinical Physiology CNR (Italy); $\varnothing$. Rideng, Kongsberg SIM (Norway);

B. Gersak, Medical Ctr. Ljubljana (Slovenia)

$6806 \mathrm{OL}$ Context-based pixelization model for the artificial retina using saliency map and skin color detection algorithm [6806-19]

S. M. Jin, I. B. Lee, J. M. Han, Seoul National Univ. (South Korea); J. M. Seo, Dongguk Univ. College of Medicine (South Korea); K. S. Park, Seoul National Univ. (South Korea) 
6806 OM Natural systems analysis [6806-20]

W. S. Geisler, J. S. Perry, A. D. Ing, Univ. of Texas at Austin (USA)

6806 ON Hyperspectral image visualization based on a human visual model [6806-21]

H. Zhang, H. Peng, M. D. Fairchild, Rochester Institute of Technology (USA); E. D. Montag, Leuze Electronic, Inc. (USA)

680600 Dynamic visual attention: motion direction versus motion magnitude [6806-22]

A. Bur, Univ. of Neuchâtel (Switzerland); P. Wurtz, R. M. Müri, Univ. of Bern (Switzerland);

H. Hügli, Univ. of Neuchâtel (Switzerland)

6806 OP Motion saliency outweighs other low-level features while watching videos [6806-23]

D. Mahapatra, S. Winkler, S.-C. Yen, National Univ. of Singapore (Singapore)

$6806 \mathrm{OQ} \quad$ Automatic video summarization driven by a spatio-temporal attention model [6806-24]

R. Barland, A. Saadane, IRCCyN, Ecole Polytechnique de I'Univ. de Nantes (France)

\section{SESSION $8 \quad$ VISUAL PERCEPTION IN THE DETECTION AND TRACKING OF OBJECTS}

6806 OR Inhibitory surround and grouping effects in human and computational multiple object tracking [6806-25]

O. Yilmaz, Univ. of Houston (USA); S. Guler, intuVision, Inc. (USA); H. Ogmen, Univ. of Houston (USA) and Ctr. for Neuro-Engineering and Cognitive Science, Univ. of Houston (USA)

6806 OS Quantifying the perceived interest of objects in images: effects of size, location, blur, and contrast [6806-26]

V. Kadiyala, S. Pinneli, E. C. Larson, D. M. Chandler, Oklahoma State Univ. (USA)

6806 OT The pupil dilation response to visual detection [6806-27]

C. M. Privitera, Univ. of California, Berkeley (USA); L. W. Renninger, Univ. of California, Berkeley (USA) and Smith-Kettlewell Eye Research Institute (USA); T. Carney, S. Klein, Univ. of California, Berkeley (USA); M. Aguilar, Teledyne Scientific Co. (USA)

$68060 \mathrm{U}$ The influence of image compression on target acquisition [6806-28]

O. Hadar, E. Goldberg, E. Topchik, Ben Gurion Univ. of the Negev (Israel)

6806 OV Adapting images to observers [6806-29]

K. C. McDermott, I. Juricevic, G. Bebis, M. A. Webster, Univ. of Nevada, Reno (USA)

\section{SESSION 9 ART, AESTHETICS, AND PERCEPTION}

6806 OW Peceptual rendering of HDR in painting and photography [6806-30]

J. J. McCann, McCann Imaging (USA)

$68060 \mathrm{X}$ The art of non-photographic imaging [6806-31]

N. Moroney, Hewlett-Packard Labs. (USA) 
6806 OY Aesthetics versus utility in electronic imaging [6806-32]

F. L. van Nes, ErgoNes (Netherlands) and Technische Univ. Eindhoven (Netherlands)

680610 On the performance of human visual system based image quality assessment metric using wavelet domain [6806-34]

A. Ninassi, Thomson Corporate Research (France) and IRCCyN, CNRS, Univ. de Nantes (France); O. Le Meur, Thomson Corporate Research (France); P. Le Callet, D. Barba, IRCCYN, CNRS, Univ. de Nantes (France)

680611 Using gaze information to improve image difference metrics [6806-35] M. Pedersen, J. Y. Hardeberg, P. Nussbaum, Gjøvik Univ. College (Norway)

680612 The effect of lightness scaling on the perceived color quality of compressed digital videos [6806-36]

C. C. Koh, Video Products Group, Inc. (USA); J. M. Foley, S. K. Mitra, Univ. of California, Santa Barbara (USA)

680613 Image group compression using texture databases [6806-37]

M. Kramm, Munich Univ. of Technology (Germany)

680614 Image mapping using local and global statistics [6806-38]

Y. Li, E. Adelson, Massachusetts Institute of Technology (USA)

680615 Analyzing the role of visual structure in the recognition of natural image content with multi-scale SSIM [6806-39]

D. M. Rouse, S. S. Hemami, Cornell Univ. (USA)

680616 A psychovisual experiment on the use of Gibbs potential for the quality assessment of geometrically distorted images [6806-40]

A. D'Angelo, M. Pacitto, M. Barni, Univ. of Siena (Italy)

680617 Structure-preserving properties of bilevel image compression [6806-41]

M. G. Reyes, Univ. of Michigan (USA); X. Zhao, Northwestern Univ. (USA); D. L. Neuhoff, Univ. of Michigan (USA); T. N. Pappas, Northwestern Univ. (USA)

\section{SESSION 11 HIGHER LEVEL ISSUES IN IMAGE QUALITY}

680618 Subjective responses to constant and variable quality video [6806-42]

D. S. Hands, K. Cheng, BT Research and Venturing (United Kingdom)

680619 Improving visual content accessibility for low-vision users in the MPEG-21 multimedia framework [6806-43]

S. Yang, J. Choi, Y. M. Ro, Information and Communications Univ. (South Korea); S.-J. Park, Electronics and Telecommunications Research Institute (South Korea)

6806 1A The colour preference control based on two-colour combinations [6806-44] J. Y. Hong, Y. Kwak, D.-S. Park, C. Y. Kim, Samsung Advanced Institute of Technology (South Korea) 
6806 1B Effect of blackness level on visual impression of color images [6806-45]

T. Eda, Y. Koike, S. Matsushima, M. Ayama, Utsunomiya Univ. (Japan)

SESSION 12 PERCEPTION, RESOLUTION, AND DISPLAY

6806 1C Adaptation of document images to display constraints (Invited Paper) [6806-46]

K. Berkner, B. Erol, Ricoh Innovations, Inc. (USA)

6806 1D Representative image thumbnails: automatic and manual [6806-47]

R. Samadani, HP Labs. (USA); T. Maver, D. Berfanger, J. Clark, HP Rainbow Image Science (USA); B. Bausk, HP.com (USA)

6806 IE Influence of camera and in-scene motion on perceived video quality in MPEG-2 adaptive coding [6806-48]

N. Van den Ende, C. Wijermans, Philips Research (Netherlands); L. Meesters, Eindhoven

Univ. of Technology (Netherlands); J. Hoonhout, Philips Research (Netherlands)

6806 IF A quality metric for use with frame-rate based bandwidth adaptation algorithms [6806-49] M. Krause, M. van Hartskamp, Philips Research Europe (Netherlands); E. Aarts, Philips Research Europe (Netherlands) and Eindhoven Univ. of Technology (Netherlands)

6806 1G Perceptual limit to display resolution of images as per visual acuity [6806-50] K. Masaoka, NHK Science and Technical Research Labs. (Japan); T. Niida, M. Murakami, K. Suzuki, International Univ. of Health and Welfare (Japan); M. Sugawara, Y. Nojiri, NHK Science and Technical Research Labs. (Japan)

INTERACTIVE PAPER SESSION

$6806 \mathrm{1H} \quad$ Unsupervised color image segmentation using a dynamic color gradient thresholding algorithm [6806-51]

G. P. Balasubramanian, E. Saber, Rochester Institute of Technology (USA); V. Misic, Thomas Jefferson Univ. (USA); E. Peskin, Rochester Institute of Technology (USA); M. Shaw, HewlettPackard Co. (USA)

680611 Comparison of eye tracking devices used on printed images [6806-52]

B. Komínková, Univ. of Pardubice (Czech Republic) and Gjøvik Univ. College (Norway); M. Pedersen, J. Y. Hardeberg, Gjøvik Univ. College (Norway); M. Kaplanová, Univ. of Pardubice (Czech Republic)

6806 iJ Evaluation of video quality models for multimedia [6806-53]

K. Brunnström, Acreo AB (Sweden); D. Hands, British Telecom (United Kingdom); F. Speranza, Communications Research Ctr., Canada (Canada); A. Webster, National Telecommunications and Information Administration (USA)

6806 1K Designing caption production rules based on face, text, and motion detection [6806-54] C. Chapdelaine, M. Beaulieu, L. Gagnon, Computer Research Institute of Montreal (Canada) 
6806 IL Human-centered content-based image retrieval [6806-55]

E. L. van den Broek, Univ. of Twente (Netherlands); T. Kok, T. E. Schouten, L. G. Vuurpijl,

Radboud Univ. Nijmegen (Netherlands)

$68061 \mathrm{M}$ Extension of a human visual system model for display simulation [6806-56]

C. Marchessoux, Barco N.V. (Belgium); A. Rombaut, Ghent Univ. (Belgium); T. Kimpe, Barco

N.V. (Belgium); B. Vermeulen, P. Demeester, Ghent Univ. (Belgium)

Author Index 


\title{
Conference Committee
}

\author{
Symposium Chair
}

Nitin Sampat, Rochester Institute of Technology (USA)

Conference Chairs

Bernice E. Rogowitz, IBM Thomas J. Watson Research Center (USA)

Thrasyvoulos N. Pappas, Northwestern University (USA)

Program Committee

Albert J. Ahumada, NASA Ames Research Center (USA)

Jan P. Allebach, Purdue University (USA)

Erhardt Barth, Universität zu Lübeck (Germany)

Walter R. Bender, MIT Media Laboratory (USA)

Michael H. Brill, Datacolor (USA)

John C. Dalton, Synthetik Software (USA)

Scott J. Daly, Sharp Laboratories of America, Inc. (USA)

Huib de Ridder, Technische Universiteit Delft (Netherlands)

Gunilla A. M. Derefeldt, Swedish Defence Research Agency (Sweden)

Elena A. Fedorovskaya, Eastman Kodak Company (USA)

Jennifer Gille, Qualcomm, Inc. (USA)

Sheila S. Hemami, Cornell University (USA)

Laurent Itti, University of Southern California (USA)

Stanley A. Klein, University of California, Berkeley (USA)

Jan J. Koenderink, Universiteit Utrecht (Netherlands)

John J. McCann, McCann Imaging (USA)

Jeffrey B. Mulligan, NASA Ames Research Center (USA)

Karol Myszkowski, Max-Planck-Institut für Informatik (Germany)

Adar Pelah, The University of York (United Kingdom)

Hawley K. Rising III, Consultant (USA)

Sabine E. Süsstrunk, École Polytechnique Fédérale de Lausanne

(Switzerland)

Christopher W. Tyler, Smith-Kettlewell Eye Research Institute (USA)

Andrew B. Watson, NASA Ames Research Center (USA)

\section{Session Chairs}

1 Keynote Session: Celebrating 20 Years of HVEI I

Bernice E. Rogowitz, IBM Thomas J. Watson Research Center (USA)

Thrasyvoulos N. Pappas, Northwestern University (USA) 
2 Keynote Session: Celebrating 20 Years of HVEI II

Bernice E. Rogowitz, IBM Thomas J. Watson Research Center (USA)

Thrasyvoulos N. Pappas, Northwestern University (USA)

3 Cortical Modeling and Representation

Stanley A. Klein, University of California, Berkeley (USA)

$4 \quad$ Perception and High Dynamic Range Displays

Thrasyvoulos N. Pappas, Northwestern University (USA)

$5 \quad$ Vision and Graphics

Bernice E. Rogowitz, IBM Thomas J. Watson Research Center (USA)

$6 \quad$ Next-generation Interactive Environments

Huib de Ridder, Technische Universiteit Delft (Netherlands)

Adar Pelah, The University of York (United Kingdom)

7 Visual Attention and Gaze

Bernice E. Rogowitz, IBM Thomas J. Watson Research Center (USA)

8 Visual Perception in the Detection and Tracking of Objects

Thrasyvoulos N. Pappas, Northwestern University (USA)

9 Art, Aesthetics, and Perception

Elena A. Fedorovskaya, Eastman Kodak Company (USA)

Hawley K. Rising III, Consultant (USA)

10 Image Statistics, Quality, and Compression

Bernice E. Rogowitz, IBM Thomas J. Watson Research Center (USA)

11 Higher Level Issues in Image Quality

Thrasyvoulos N. Pappas, Northwestern University (USA)

12 Perception, Resolution, and Display

Ramin Samadani, Hewlett-Packard Laboratories (USA)

Thrasyvoulos N. Pappas, Northwestern University (USA) 


\section{Introduction}

This volume of the Proceedings celebrates 20 years of the Conference on Human Vision and Electronic Imaging (HVEI)! The goal of this conference is to explore the role of human vision, perception, and cognition in the design, analysis, and use of computer-based image and data systems. Over the years, HVEl has brought together researchers from a wide variety of disciplines, from all over the world, for a rich and lively exchange of ideas. This dialog is based on the growing understanding that the human observer is a fundamental key to the advancement of image systems, and that advances in these systems and applications stimulate new research into the vision, perception, and cognition of the human observer. You can find information on our past conferences and the HVEl community at httt://www.eecs.northwestern.edu/ pappas/hvei. We want to thank all those who participated in and contributed to the conference during these past twenty years. We are looking forward to the next twenty!

Bernice E. Rogowitz Thrasyvoulos N. Pappas 
Downloaded From: https://www.spiedigitallibrary.org/conference-proceedings-of-spie on 26 Apr 2023

Terms of Use: https://www.spiedigitallibrary.org/terms-of-use 